\title{
不同蒸发器结构的超薄平板环路热管的传热性能的 差异化
}

洪思慧, 唐永乐, 张新强, 汪双风*, 张正国

华南理工大学, 传热强化与过程节能教育部重点实验室, 广州 510640

* 联系人, E-mail: sfwang@ @scut.edu.cn

2016-06-11 收稿, 2016-07-23 修回, 2016-07-23 接受, 2016-09-12 网络版发表 新能源汽车用动力电池高性能的研究国际合作项目(2013DFG60080)资助

摘要开发设计了两款无毛细结构的超薄型 $(1.5 \mathrm{~mm}$ 厚)铜-水平板环路热管, 并对其多方位下热传输性能进行 实验研究. 对比分析了两种蒸发器结构的热管在不同角度下的启动能力和运行特性, 且探究了蒸发器结构对于超 薄环路热管运行稳定性的影响, 以及热管性能在多方位条件下的差异. 实验表明两种结构热管均能满足多方位工 作的要求, 具有抗重力特性, 其中平行四边形的结构设计有助于抑制流动不稳定, 抗重力性能更优, 不仅能够在 $15^{\circ}$ 时启动，而且不同角度下热传输性能的差异仅为 $4 \%$.

关键词超薄, 热传输性能, 多方位, 差异, 运行稳定性

环路热管(loop heat pipe, LHP)是一种高效的相 变传热装置, 由汽液传输管路连成回路, 并利用工质 的相变来传递热量 ${ }^{[1]}$, 具有汽液管路分离、蒸发器和 补偿器一体化等结构特点, 从而决定了其气液携带 阻力小、启动快速灵活、多方位长距离传输热量的 传热特点. 随着电子散热的迅速发展, 能与电子元件 表面紧密贴合的微小型平板环路热管受到关注 ${ }^{[2,3]}$. 但传统环路热管热传输能力的提升受制于毛细芯结 构的发展, 毛细结构要求既要具备较高的毛细极限 又要保证较低的流动阻力 ${ }^{[4,5]}$, 且毛细芯容易引起漏 热, 增加LHP的低温启动难度. 而毛细芯结构通常较 厚重, Kiseev等人 ${ }^{[6]}$ 实验发现多孔毛细芯厚度在 5 7 $\mathrm{mm}$ 时蒸发器效果最优. 而利用微小通道作为强化换 热手段一直被广泛关注, 利用微小通道强化传热的 特性, 结合环路热管汽液分离的结构特点, 在蒸发器 内用微小槽道组替代毛细芯, 开发设计了新型的超 薄平板环路热管 ${ }^{[7]}$ (ultra-thin looped heat pipe, ULHP),
其性能及应用亟待深入探讨. 类似形式的热管有分 离式虹吸管(two-phase loop thermosyphon), 但目前 所报道的虹吸管基本都是考查其在垂直条件下的工 作特性 ${ }^{[8 \sim 11}$, 并不像LHP具有多方位运输的特点. 因 此，考查超薄平板热管在不同角度下是否能正常工 作及其工作能力如何对ULHP的实际应用具有重要 指导意义.

微小通道内流动沸腾的基础研究发展很快，包 括其内的两相流流型研究 ${ }^{[12 ~ 17]}$, 传热机理研究 ${ }^{[18 ~ 22] ~}$

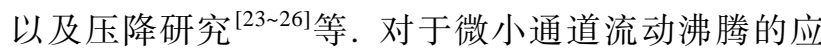
用研究, 最主要的挑战是由于通道限制, 气泡变形过 快引发的温度/压力波动和流动不稳定性 ${ }^{[27]}$. 流动不 稳定性对设备、装置的影响极大，通道中原有的流 体动力学状态被破坏, 换热系数变化, 传热性能急剧 下降，导致临界热流量提前来临 (pre-critical heat flux)，造成局部烧干，引起瞬时表面温度的茠升和压 力的大幅波动. 特别是在水平和小角度放置时，流动

引用格式: 洪思慧, 唐永乐, 张新强, 等. 不同蒸发器结构的超薄平板环路热管的传热性能的差异化. 科学通报, 2017, 62: 721-729

Hong S H, Tang Y L, Zhang X Q, et al. Multiple orientations research on heat transfer capabilities of ultra-thin loop heat pipes with various channel configurations (in Chinese). Chin Sci Bull, 2017, 62: 721-729, doi: 10.1360/N972016-00036 
不稳定现象更为严重. 主动考虑并有效抑制流动不 稳定性能够提高临界热流量, 强化换热系数, 保证系 统的稳定工作. 目前, 减小微小通道内流动不稳定性 的方法主要有对人口结构的限制式设计 ${ }^{[28]}$, 设置扩

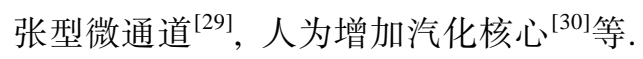

针对可多方位工作的超薄平板环路热管, 其蒸 发器内的微小通道在起到强化传热的作用同时, 也 会带来流动不稳定性和压力、温度的波动, 引发热 传输性能的衰退, 尤其是因角度变化导致不稳定性 加剧而引发的性能差异将限制ULHP的实际应用范 围. 因此, 本文针对解决流动不稳定性以促进超薄环 路热管内工质的循环效率为目的, 设计了槽道排布 呈平行四边形和槽道排布呈梯形的两种蒸发器结构 的ULHPs, 并在不同角度下全面考查两者热传输性 能的差异, 及其对于抑制流动不稳定性的有效性, 得 出这两种超薄型环路热管抗重力条件下的工作性能, 并验证了环路热管轻薄化的有效性.

\section{1 实验系统}

本文所研究的环路热管如图1所示, 其蒸发器为 平板结构, 总厚度是 $1.5 \mathrm{~mm}$. 蒸发器与外环路管线 均由铜制成, 系统以水作为工质, 具体的结构参数见 表1. 此外, 实验系统还由加热装置、冷凝装置、数 据采集装置和固定装置等四部分联合组成. 加热装 置由开有沟槽的承载台、三根加热铜棒以及与蒸发 器大小相同的薄铜片. 铜棒放置于承载台的沟槽内, 由直流稳压电源 (兆信KXN-645D)进行加热, 与薄铜 片通过压条紧密贴合作为热源, 并紧贴蒸发器表面,
保证受热的均一性. 冷凝装置包括翅片组、风道、风 扇(PF70201V1-000C-A99), 采用直流稳压电源(兆信 KXN-645D) 控制风扇的功率, 通过风道冷却翅片组 进而实现冷却效果. 数据采集装置由安捷伦34970 A 和温度采集模块 01 对环路的各部位共 13 个布温点, 使用 $\mathrm{K}-\mathrm{OMEGA}$ 热电偶 $\left(\right.$ 精度为 $\pm 0.5^{\circ} \mathrm{C}$ ) 进行数据变动 记录. 外环路总长度为 $445 \mathrm{~mm}$, 冷凝部的长度为 160 $\mathrm{mm}$. 固定装置包括可调支架台, 加热部压条等. 实 验系统垂直放置, 依靠重力解决无毛细回流问题. 加 热功率的变化通过调节直流稳压电源的电压实现, 冷凝能力的大小通过调节风扇的输人电压进行调节. 热管样品及其内部微槽结构见图 1, 实验台的示意图 及实景图参见图 2 .

所做实验均在环境温度为 $24^{\circ} \mathrm{C}$ 的条件下进行, 环境温度由室内空调设定和控制. ULHP外环路管线 和蒸发器表面都包裹石棉网以减小漏热, 该石棉网

表 1 超薄型环路热管的结构参数

Table 1 The structure parameters of ULHP

\begin{tabular}{ll}
\hline \multicolumn{1}{c}{ 参数 } & \multicolumn{1}{c}{ 值 } \\
\hline 蒸发器的长×宽×高 & $160 \mathrm{~mm} \times 115 \mathrm{~mm} \times 1.5 \mathrm{~mm}$ \\
蒸发器内槽道长×宽×高 & $105 \mathrm{~mm} \times 3 \mathrm{~mm} \times 0.6 \mathrm{~mm}$ \\
蒸发器内槽道间距 & $3 \mathrm{~mm}$ \\
蒸发器内槽道数 & 25 条 \\
蒸发器壁材 & 铜 \\
外环路总长度 & $445 \mathrm{~mm}$ \\
管线的内径/外径 & $2.4 \mathrm{~mm} / 3 \mathrm{~mm}$ \\
工质 & 水 \\
工质充装量 & $5.0 \mathrm{~g}$ \\
\hline
\end{tabular}

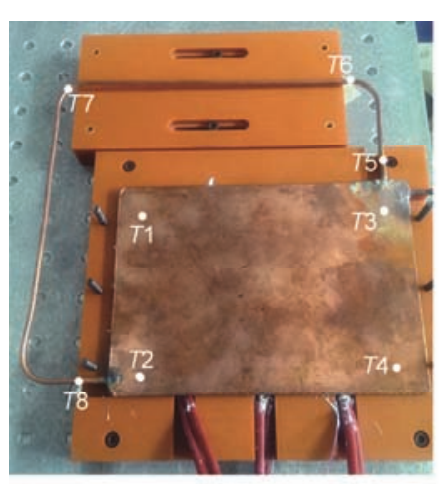

(a)
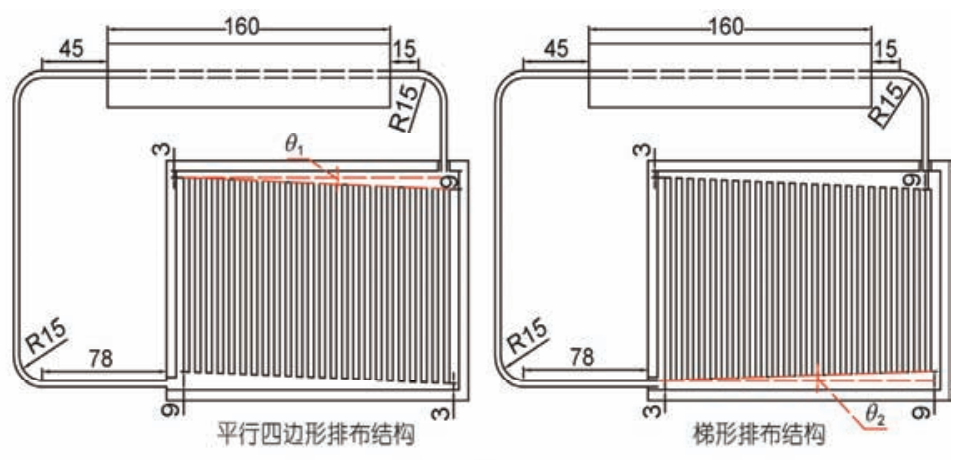

(b)

图 1 (网络版彩色)热管样品及其内部槽道结构. (a) 样品实物; (b) 内部槽道结构

Figure 1 (Color online) The structure of the designed samples of ULHP. (a) The ULHP protype; (b) the schematic diagram of channel configurations (parallelogram \& trapezoid) 


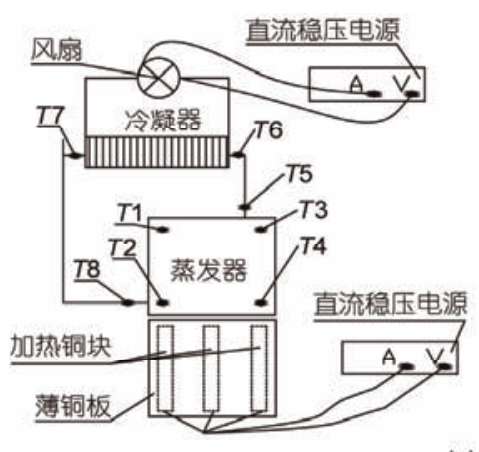

(a)

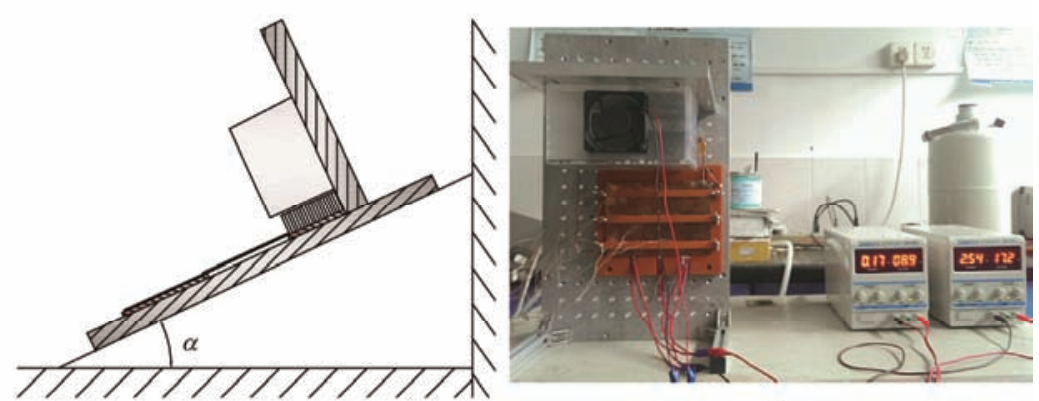

(b)

图 2 (网络版彩色) 实验台示意图及实物图. (a) 实验系统示意图; (b) 实验台实景

Figure 2 (Color online) The experimental set-up schematic diagram and apparatus. (a) Schematic diagram of experimental set-up; (b) experimental apparatus

的热导率为 $0.034 \mathrm{~W} /(\mathrm{K} \mathrm{m})$. 另外, 加热铜板和冷凝器 下方均垫有枕木, 枕木的导热系数为 $0.051 \mathrm{~W} /(\mathrm{K} \mathrm{m})$, 在支撑部件的同时也能有效减小热管向金属支架的 漏热. 经多次实验并计算验证, 每次实验的总热损小 于 $2 \%$. 实验过程不可避免存在实验误差, 根据《中华 人民共和国国家计量技术规范JJF1059-1999》, 实验 中直接观测的测量值不确定可由 $\mathrm{A}$ 类不确定度分析 给出, 对于同一条件下的实验采用多次重复测试的 手段, 保证实验现象的可重复性和有效性, A类不确 定度由 $U\left(T_{i}\right)=\sqrt{\frac{1}{m(n-1)} \sum_{j=1}^{m} \sum_{i=1}^{n}\left(T_{i j}-\bar{T}_{i}\right)}$ 计算, 则温度值 的最大不确定性计算得到为 $1.83^{\circ} \mathrm{C}$. 由仪器带来的不 确定性可由 $\mathrm{B}$ 类不确定度给出, $U\left(X_{i}\right)=a / k$, 其中, $a$ 是 说明书上标称的误差范围, $k$ 是根据 $X_{i}$ 的分布得到的 包含因子. 采用矩形分布估计, $k$ 为 $\sqrt{3}$. 因此在本实 验中, 热电偶的测试不确定度为 $\pm 0.289^{\circ} \mathrm{C}$, 由直流稳 压电源提供的加热功率以及风扇功率的不确定性在 $5.77 \%$ 以下, 环境温度的不确定性控制在 $\pm 0.8^{\circ} \mathrm{C}$ 以内.

\section{2 结果与讨论}

\section{1 启动特性}

由于没有毛细芯, 超薄平板环路热管内部工质
运行的推动力依赖于重力和相变压差. 非垂直条件 下, 推动力减小, 蒸气工质的单向循环流动难以保 障, 启动难度增大, 甚至无法启动. 因此, 对ULHP 临界工作角度的确定, 实质是对该款热管最低工作 能力的界定, ULHP启动的临界角度将限制其实际应 用的广度. 考察两种结构的ULHP在不同角度下的启 动情况, 其结果如表2所示.

受内部结构的影响, 两种结构的ULHP在启动能 力上有显著差异. 槽道排布呈平行四边形结构的 ULHP $15^{\circ}$ 放置时已能够在 $50 \mathrm{~W}$ 的热负荷下经 $2600 \mathrm{~s}$ 左右启动, 但梯形结构ULHP水平放置时无法启动, 直到倾角增大至 $30^{\circ}$ 时才能正常工作, 且仍需 $3000 \mathrm{~s}$ 的启动时间. 对比来说, 各角度下平行四边形结构的 启动都更迅速, 且启动所需的热负荷也更低, 说明内 部工质的单向循环流动能够更快速更稳定地建立, 这得益于槽道呈平行四边形排布时在人口处形成的 “液池”结构.

工质是否形成单向循环可由冷凝器人口处 $T_{6}$ 和 蒸发器人口处 $T_{8}$ 的温度差反映. 即 $\Delta T_{6-8}=T_{\mathrm{e} 6}-T_{\mathrm{e} 8}$. $\Delta T_{6-8}$ 的波动, 反映的是内部工质的不断振荡, 当系 统启动, $\Delta T_{6-8}$ 应为正值且不断增大而波动逐渐减少. 图3是两种结构的ULHP在临界角度下的启动特性曲 线. 根据上述分析, 平行四边形的ULHP在水平放置

表 2 各角度下两种结构ULHP的启动功率和启动时间对比

Table 2 The heat loads and durations for the two ULHP samples to start-up

\begin{tabular}{|c|c|c|c|c|c|c|}
\hline 结构 & $0^{\circ}$ & $15^{\circ}$ & $30^{\circ}$ & $45^{\circ}$ & $60^{\circ}$ & $90^{\circ}$ \\
\hline 平行四边形 & I & $40 \mathrm{~W} / 2614 \mathrm{~s}$ & $30 \mathrm{~W} / 2350 \mathrm{~s}$ & $30 \mathrm{~W} / 2158 \mathrm{~s}$ & $30 \mathrm{~W} / 1880 \mathrm{~s}$ & $30 \mathrm{~W} / 700 \mathrm{~s}$ \\
\hline 梯形 & I & / & $40 \mathrm{~W} / 2996 \mathrm{~s}$ & $40 \mathrm{~W} / 2630 \mathrm{~s}$ & $30 \mathrm{~W} / 2546 \mathrm{~s}$ & $30 \mathrm{~W} / 1600 \mathrm{~s}$ \\
\hline
\end{tabular}


时启动响应快, $\Delta T_{6-8}$ 的正向温差迅速增大, 约 $600 \mathrm{~s}$ 时建立, 但此时工质的热动力不足, 启动不稳定, 至 $2600 \mathrm{~s}$ 时, 系统完全启动. 而梯形ULHP的漏热严重, 启动响应慢, $\Delta T_{6-8}$ 的正向温差直到 $1100 \mathrm{~s}$ 左右才形 成, 此后也经历不稳定过程, 但波动幅度较大, 两相 流工质反冲严重, 直到2996 s, 系统的正向循环才完 全建立.

\section{2 蒸发器平均温度}

由于两种结构的ULHP在 $30^{\circ}$ 以后均能启动并稳 定工作, 故文中后续对其他热传输性能的差异化进 行比较时, 选取放置角度在 $30^{\circ} \sim 90^{\circ}$ 范围内进行. 图4 对比了两种结构的ULHP在不同角度下各自的蒸发 器平均温度随热负荷的变化规律. 很明显, 对于槽道 形状呈平行四边形排布的ULHP, 蒸发器平均温度随 放置角度的变化不大, 倾斜角在 $30^{\circ} \sim 60^{\circ}$ 区间内时, 温度的平均变化差异为 $4 \%$; 即使与极限情况垂直放 置时相比, 蒸发器平均温度的变化也不超过 $10 \%$, 说 明槽道排布呈平行四边形结构的ULHP具有良好的 抗重力性能, 放置角度对其传热性能的影响较小. 而 放置角度对梯形结构ULHP传热能力的影响则明显 增加. 各角度下蒸发器平均温度相差较大, 由角度变 化引起的平均差异约为 $7.8 \%$, 而与垂直放置时的状 况相比, 其温度变化的幅度高达 $20 \%$.

图 5 对比了两种结构的ULHP的蒸发器平均温度
在不同放置角度下的具体差异, 反映的是角度对两 者热传输性能差异的影响. 可以看出, 两种排布形状 的ULHP的蒸发器温度差异随着角度的增大而显著 减小, 垂直条件下, 两种结构的热传输性能差别很 小, 启动后, 在 $100 \mathrm{~W}$ 的热负荷范围内, 两者蒸发器 平均温度几乎相同; 但在倾斜角度为 $30^{\circ}$ 时两者的最 大温差达到 $9.11^{\circ} \mathrm{C}$, 因此对比来说, 平行四边形的抗 重力性能更好, 而梯形结构的ULHP的热传输能力随 着角度的增加明显衰减.

\section{3 运行稳定性}

两种排布结构最大的区别就在于人口处形成的 “液池”结构, 其作用在于减小蒸发器槽道内两相工 质的流动不稳定性影响, 保证工质的单向稳定循环, 从而提高系统的传热性能. $T_{8}$ 位于蒸发器人口处, 既 受到回流冷液补充的影响, 又受到蒸发器漏热及其 内工质反冲的影响, 是整个系统中温度波动最大, 运 行最不稳定的位置. 对各角度下两种结构 $T_{8}$ 处的温 度波动情况进行分析, 能够进一步说明“液池”结构 对于稳定工质的单向循环的效果. 图6(a)和(b)分别是 平行四边形结构和梯形结构不同角度下 $T_{8}$ 处的温度 波动随热负荷的分布情况. 首先, 槽道呈平行四边形 排布结构时, $T_{8}$ 处的温度波动范围在 $\pm 6^{\circ} \mathrm{C}$ 内, 而梯形 结构下, 温度的波动范围明显扩大至 $\pm 12^{\circ} \mathrm{C}$, 说明“液 池”能够有效地抑制人口处的温度波动, 减小回流的

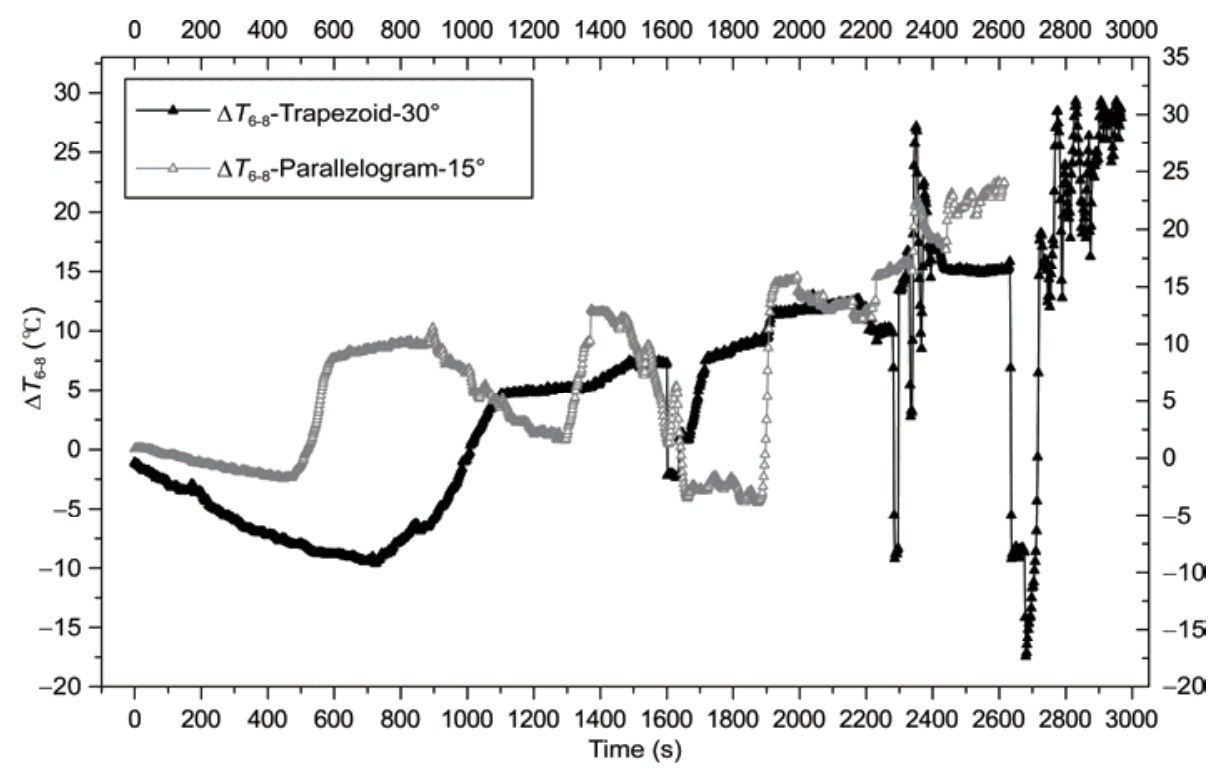

图 3 临界角度下两种结构的ULHP的启动特性曲线

Figure 3 The start-up characteristic curves of two ULHP samples under the critical angels 

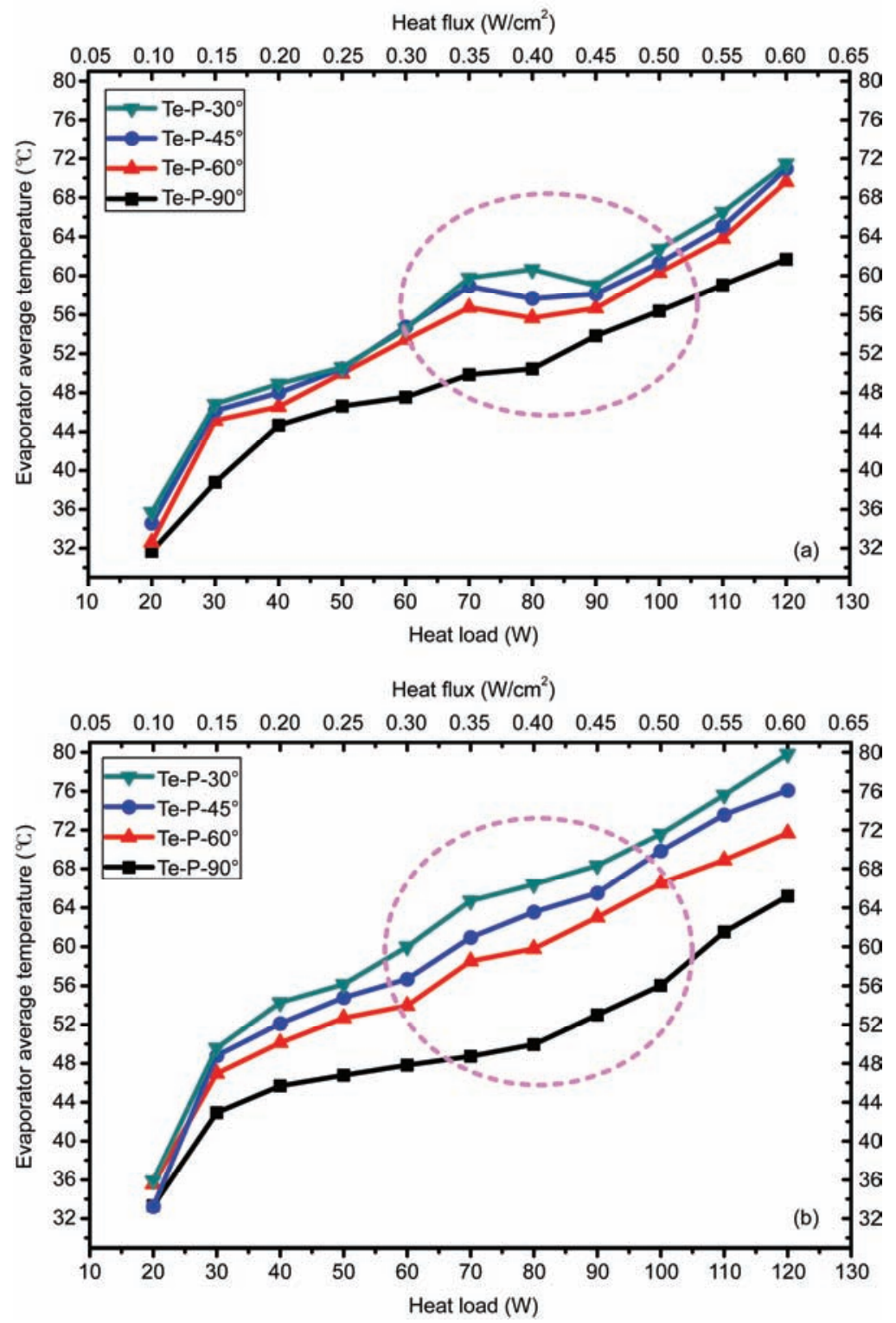

图 4 (网络版彩色) 不同角度下, 两种结构ULHP的蒸发器平均温度随热负荷的变化. (a) 平行四边形结构ULHP; (b) 梯形结构ULHP

Figure 4 (Color online) The variations of the evaporator average temperature of the two ULHP samples along with the heat loads under different orientations. (a) The parallelogram configuration; (b) the trapezoid configuration

冷液工质补充进人蒸发器的阻力，且利于蒸气工质 的加速流出, 即能抑制入口处流动不稳定性, 保证工 质循环的稳定性和单向性. 其次, 对于平行四边形结 构的ULHP, 其温度波动的变化随放置角度的变化并 不大, 一致性较好, 抗重力能力强, 这也与上述讨论 结果相吻合.

\section{4 热阻}

根据环路热管的工作特性和原理, 可定义平板
式环路热管的环路热阻为

$$
R=\left(T_{\text {Evap }}-T_{\text {Cond }}\right) / Q_{\text {in }} .
$$

热阻是评价热管能力的直观指标，上述对启动 性能和蒸发器均温的讨论也可由热阻得到反映. 图7 是两种结构下ULHP的热阻在不同角度下随热负荷 的变化情况. 相比梯形结构的ULHP，槽道分布呈平 行四边形结构排布的ULHP的热阻明显较低, 平均低 $21 \%$ 左右，这是由于梯形结构人口处无“液池”的缓冲 

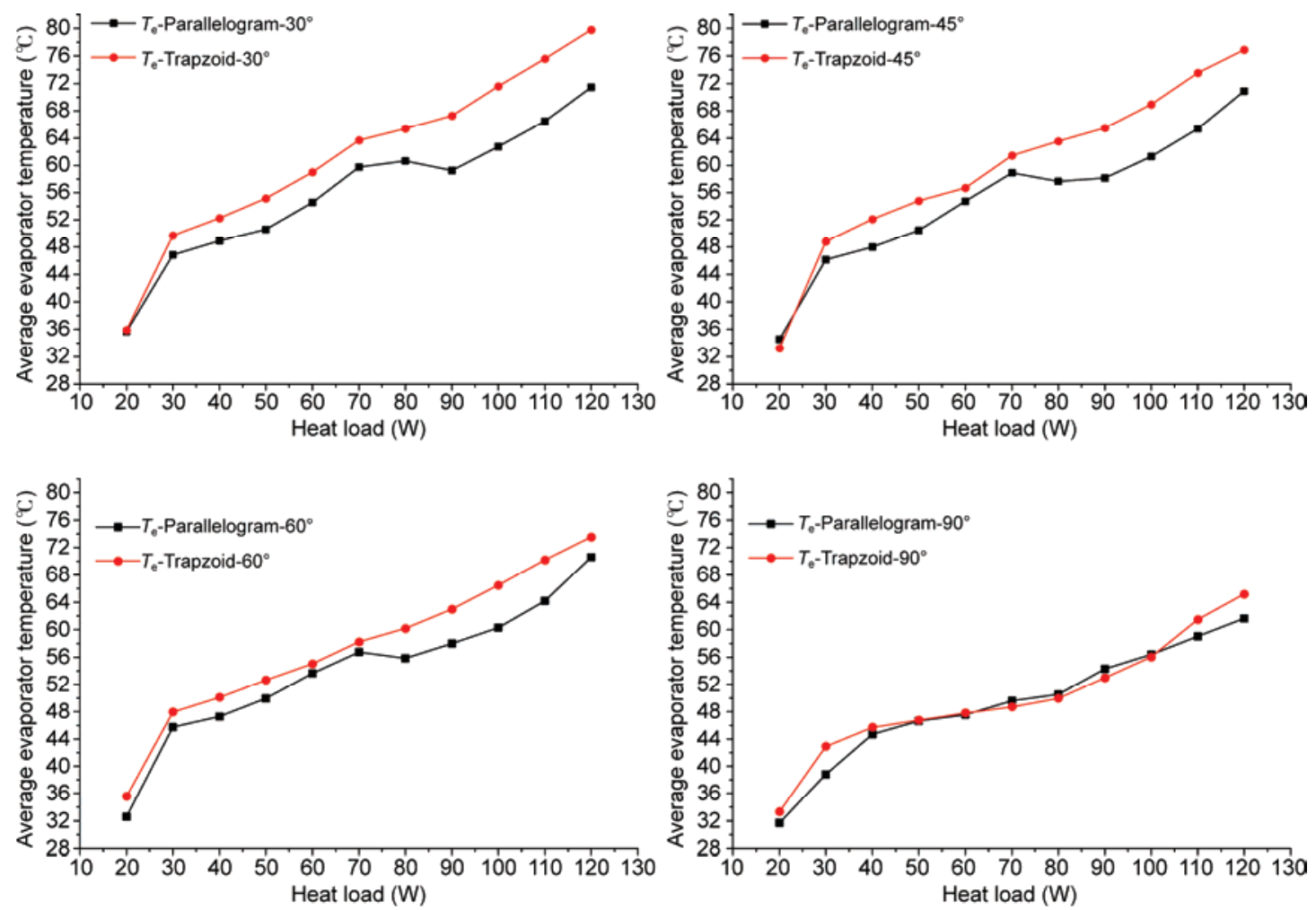

图 5 (网络版彩色)两种结构下ULHP的蒸发器平均温度的差异随角度的变化

Figure 5 (Color online) The difference of evaporator average temperature between the two ULHP samples under different angles
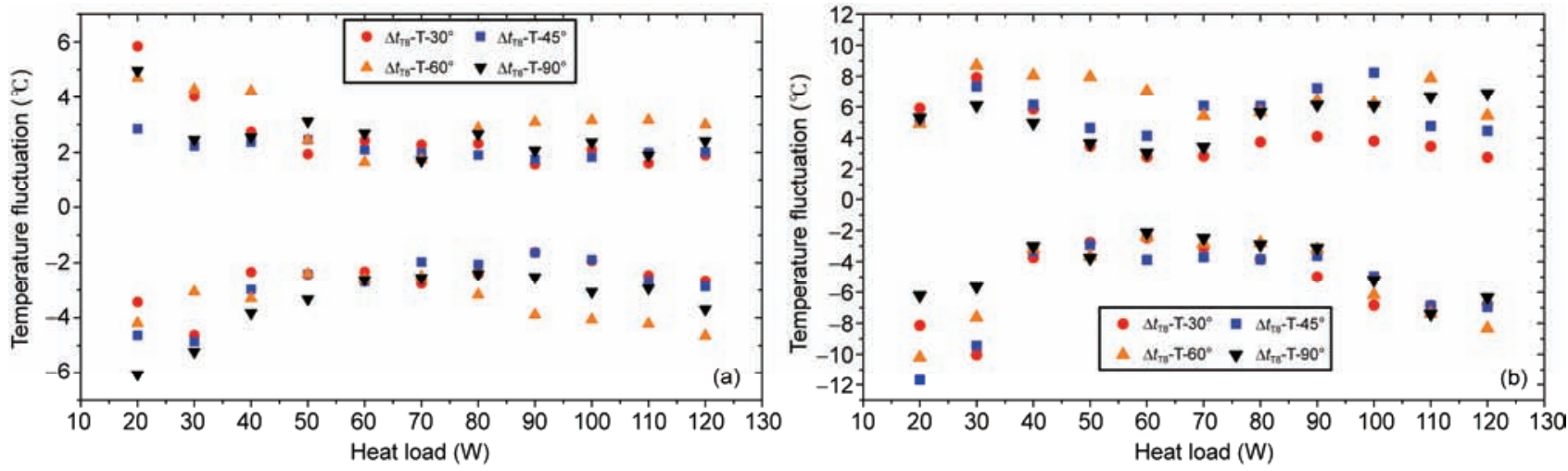

图 6 (网络版彩色)不同角度下, $T_{8}$ 处温度波动的差异. (a) 平行四边形结构ULHP; (b) 梯形结构ULHP

Figure 6 (Color online) The variations of temperature oscillation along with the angles for the two ULHP samples. (a) The parallelogram configuration; (b) the trapezoid configuration

作用, 梯形结构下工质的流动不稳定性现象加剧, 温 度振荡频繁, 较难建立稳定的单向循环, 恶化了系统 的传热能力. 梯形结构下ULHP的热传输性能受角度 的影响更显著, 这一点也反映在热阻情况的对比中, 此结构下各角度下热阻的差值更大. 在垂直放置时, 作为驱动力的重力起决定性作用, 系统启动后, 两种 结构下工质的循环都更为顺畅, ULHP的运行也更为
高效，故此时其热阻都大幅降低但相差不大.

\section{3 结论与展望}

通过对两款具有不同蒸发器结构的超薄平板环 路热管在不同角度下的热传输性能差异进行实验探 究，全面了解了这两种结构ULHP的性能，明确了蒸 发器的结构特点对于超薄平板环路热管运行过程, 


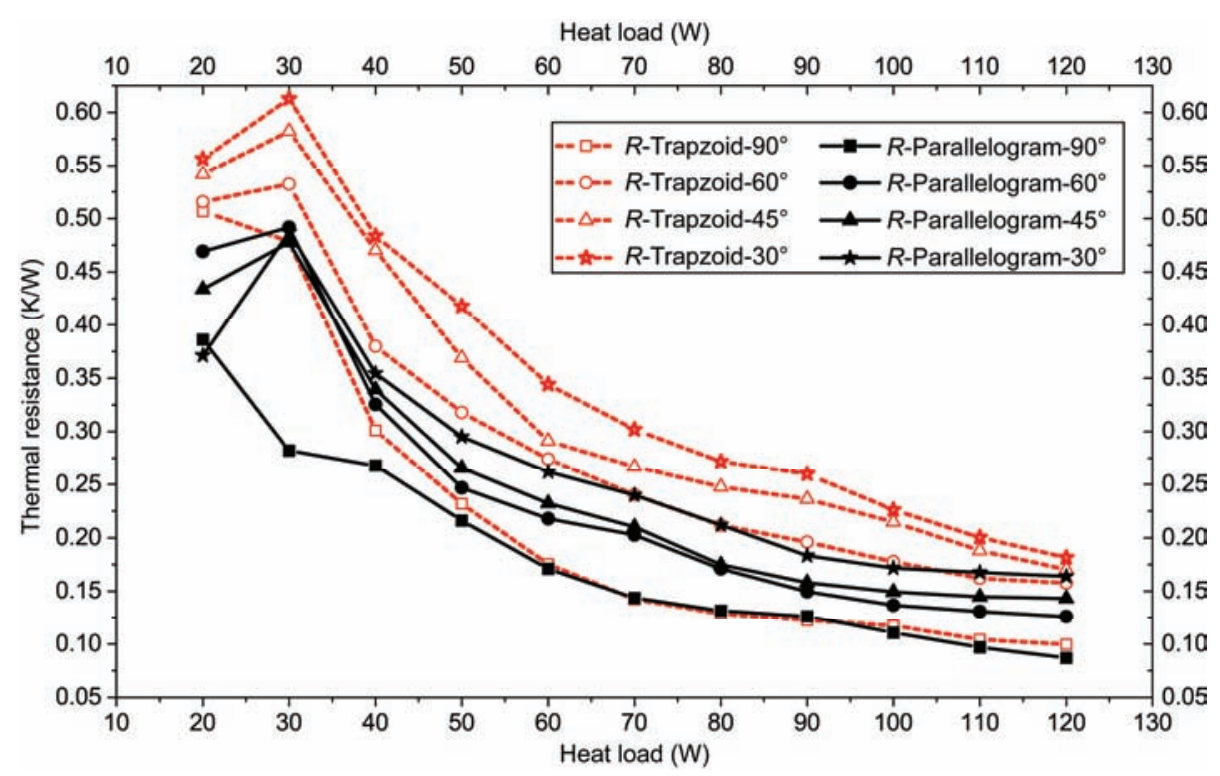

图 7 (网络版彩色)两种结构下ULHP的热阻的差异随角度的变化

Figure 7 (Color online) Variations of thermal resistances along with heat loads for the two ULHP samples under different angles

即其内部工质流动与传热过程的影响, 对超薄平板环 且循环效率提升, 热传输能力增强.

路热管进一步的优化设计有指导意义, 得到如下结论.

(1) 两种ULHP的临界工作角度不同. 平行四边 形结构下ULHP在 $15^{\circ}$ 时能够稳定启动并工作; 梯形 结构下ULHP的临界工作角度为 $30^{\circ}$. 平行四边形的 排布结构更有助于保证工质的单向循环流动, 系统 的启动响应更快.

(2) 两种ULHP的抗重力性能不一致. 平行四边 形结构的ULHP的抗重力性能更好, 不同倾角下的热 传输性能差异小, 蒸发器平均温度的平均差异为 $4 \%$, 最大差异为 $10 \%$; 而梯形结构下的平均差异达到 $7.8 \%$, 最大差异扩大至 $20 \%$. 平行四边形结构的优越 性在小角度下更为显著.

(3) 平行四边形排布时存在的“液池”结构对于 削弱系统内工质的流动不稳定性起到重要作用, 温 度波动明显减小, 系统能更快建立稳定的单向循环,

\section{符号说明}

$\begin{array}{ll}i & \text { 测试的次数 } \\ j & \text { 变量编号 } \\ k & \text { 分布因子 } \\ m & \text { 测试总数 } \\ n & \text { 变量总数 } \\ Q_{\text {in }} & \text { 输人热负荷 } \mathrm{W} \\ R & \text { 热阻 } \mathrm{K} / \mathrm{W} \\ T_{\text {evap }} & \text { 蒸发器的平均温度, 蒸发器表面个点 } T_{1} \sim T_{4} \\ & \text { 的温度平均值 } T_{\text {eavp }}=\left(T_{1}+T_{2}+T_{3}+T_{4}\right) / 4 \mathrm{~K} \\ T_{\text {cond }} & \text { 冷凝器的平均温度, 冷凝器进出口 } T_{6} \text { 和 } T_{7} \text { 的 } \\ & \text { 温度平均值 } T_{\text {cond }}=\left(T_{6}+T_{7}\right) / 2 \mathrm{~K} \\ U & \text { 不确定性 } \\ X & \text { B类实验误差 }\end{array}$

\section{参考文献}

1 Xiang Y C, Hou Z Q, Zhang J X. The state-of-the-art of loop heat pipe (in Chinese). J Eng Thermophys, 2004, 25: 682-684 [向艳超, 侯 增棋, 张加迅. 环路热管技术(LHP)的发展现状. 工程热物理学报, 2004, 25: 682-684]

2 Li J, Wang D, Peterson G P. Experimental studies on a high performance compact loop heat pipe with a square flat evaporator. Appl Therm Eng, 2010, 30: 741-752

3 Wu S C, Peng J C, Lai S R, et al. Investigation of the effect of heat leak in loop heat pipes with flat evaporator. In: Proceedings of the 4th International Microsystems Packaging Assembly and Circuits Technology Conference. New York: IEEE, 2009

4 Zan K J, Zan C J, Chen Y M, et al. Analysis of the parameters of the sintered loop heat pipe. Heat Transfer-Asian Res, 2004, 33: 515-526 
5 Xu J Y, Zou Y, Cheng L. Optimization and properties of composite wicks for loop heat pipes (in Chinese). Proc Chin Soc Electrical Eng, 2012, 32: 70-74 [徐计元, 邹勇, 程林. 环路热管复合毛细芯的孔结构优化与性能研究. 中国电机工程学报, 2012, 32: 70-74]

6 Kiseev V M, Vlassov V V, Muraoka I. Experimental optimization of capillary structures for loop heat pipes and heat switches. Appl Therm Eng, 2010, 30: 1312-1319

7 Hong S H, Zhang X Q, Wang S F, et al. Experiment study on heat transfer capability of an innovative ultra-thin loop heat pipe. Int J Therm Sci, 2015, 96: 106-114

8 Maydanik Y F, Chernysheva M A, Pastukhov V G. Review: Loop heat pipes with flat evaporators. Appl Therm Eng, 2014, 89: 294-307

9 Alessandro F, Sauro F. Closed loop two-phase thermosyphon of small dimensions: A review of the experimental results. Micrograv Sci Tech, 2012, 24: 165-179

10 Grakovich L P, Rabetsky M I, Jr Vasiliev L L, et al. Polymer flat loop thermosyphons. In: Proceedings of 17th International Heat Pipe Conference (17th IHPC). Kanpur, 2013. 13-17

11 Rahmatollah K, Björn P. Influence of system pressure on the boiling heat transfer coefficient in a closed two-phase thermosyphon loop. Int J Therm Sci, 2002, 30: 619-624

12 Bertsch S S, Groll E A, Garimella S V. Refrigerant flow boiling heat transfer in parallel microchannels as a function of local vapor quality. Int J Heat Mass Transfer, 2008, 35: 4775-4787

13 Peng X F, Xiang G M, Hu H Y, et al. Enhancing the critical heat flux using microchanneled surfaces. J Enhanc Heat Trans, 1998, 5: $165-176$

14 Ahmed W H, El-Nakla M A, Ismail B I. Towards understanding the critical heat flux for industrial applications. Int J Multiphase Flow, 2010, 36: 153-165

15 In S, Jeong S. Flow boiling heat transfer characteristics of R123 and R134a micro-channel. Int J Multiphase Flow, 2009, 35: 987-1000

16 Qi S L, Zhang P, Wang R Z, et al. Flow boiling of liquid nitrogen in micro-tubes: Part I-The onset of nucleate boiling, two-phase flow instability and two-phase flow pressure drop. Int J Heat Mass Transfer, 2007, 50: 4999-5016

17 Tran T N, Wambsganss M W, France D M. Small circular- and rectangular-channel boiling with two refrigerants. Int J Multiphase Flow, 1996, 22: 485-498

18 Bao Z Y, Fletcher D F, Haynes B S. Flow boiling heat transfer of Freon R11 and HCFC 123 in narrow passages. Int J Heat Mass Trans, 2000, 43: 3347-3358

19 Huo X, Chen L, Tian Y S, et al. Flow boiling and flow regimes in small diameter tubes. Appl Therm Eng, 2004, 24: 1225-1239

20 Pettersen J. Flow vaporization of $\mathrm{CO}_{2}$ in microchannel tubes. Exp Therm Fluid Sci, 2004, 28: 111-121

21 Yun R, Kim Y, Kim M S. Convective boiling heat transfer characteristics of $\mathrm{CO}_{2}$ in microchannels. Int J Heat Mass Transfer, 2005, 48: 235-242

22 Choi K I, Pamitran A S, Oh J T. Two-phase flow heat transfer of $\mathrm{CO}_{2}$ vaporization in smooth horizontal minichannels. Int J Refrig, 2007, 30: 767-777

23 Lin S, Kew P A, Cornwell K. Flow boiling of refrigerant R141b in small tubes. Chem Eng Res Des, 2001, 79: 417-424

24 Diaz M C, Schmidt J. Experimental investigation of transient boiling heat transfer in microchannels. Int J Heat Fluid Flow, 2007, 28: 95-102

25 Ong C L, Thome J R. Macro-to-microchannel transition in two-phase flow: Part 1-Two-phase flow patterns and film thickness measurements. Exp Therm Fluid Sci, 2011, 35: 37-47

26 Pamitran A S, Choi K 1, Oh J T, et al. Two-phase flow heat transfer of propane vaporization in horizontal minichannels. J Mech Sci Technol, 2009, 23: 599-606

27 Leonardo C R, Christian P M, Alejandro C. Two-phase flow instabilities: A review. Int J Heat Mass Trans, 2014, 71: 521-548

28 Wang G, Cheng P, Bergles A E. Effects of inlet/outlet configurations on flow boiling instability in parallel microchannels. Int J Heat Mass Trans, 2008, 51: 2267-2281

29 Balasubramanian K, Lee P S, Jin L W, et al. Experimental investigations of flow boiling heat transfer and pressure drop in straight and expanding microchannels-A comparative study. Int J Therm Sci, 2011, 50: 2413-2421

30 Kuo C J, Pe1es Y. Local measurement of flow boiling in structured surface microchannels. Int J Heat Mass Trans, 2007, 50: 4513-4526 


\title{
Multiple orientations research on heat transfer capabilities of ultra-thin loop heat pipes with various channel configurations
}

\author{
HONG SiHui, TANG YongLe, ZHANG XinQiang, WANG ShuangFeng ${ }^{*}$ \& ZHANG ZhengGuo \\ Key Laboratory of Heat Transfer Enhancement and Energy Conservation of Ministry of Education, South China University of Technology, \\ Guangzhou 510640, China \\ * Corresponding author, E-mail: sfwang@ scut.edu.cn
}

Battery thermal management system (BTMS) technology attracted more and more attentions as the new-energy automobile industry has gotten swift and violent progress in a few decades. So far, the widely used technologies include air cooling, liquid cooling and Phase Change Material (PCM) cooling. However, a common problem exists in all used technologies is the complex structures as well as the huge weight and volume, which not only increases the extra energy consuming, but also goes against the development requirement of automobile lighting. In the future, it is required without doubt that the battery thermal management system should be conveniently installed, light in weight and compact in volume, and minimized in secondary energy consumption. Thus, as a passive and effective heat transfer method, the heat pipe technology would be quite match the requirement and able to be further applied in BTMS.

In order to cater to the developed requirement of lightweight design in battery thermal management system, ultra-thin loop heat pipe (ULHP) prototypes with only $1.5 \mathrm{~mm}$ in thickness were developed. The ultra-thin design was achieved by replacing the traditional capillary core structure with micro channels, which however required extra assistance from the gravity for the ULHP system to operate, and brought about the risk of flow instability at the same time. To fully understand the exact effect of channel configuration on the heat transfer performance of ULHP, and conquer the adverse impact caused by flow boiling in micro channels, two different channel configurations inside the evaporator (parallelogram and trapezoid) were special developed and compared. Their dissimilarities in heat transfer characteristic were studied and compared under multi orientations with experiments, which could be divided into various aspects, the critical work angle, as well as the start-up characteristic, the thermal resistance and the flow instability et al, so as to completely reflect the $r$ respective influences of the parallelogram and trapezoid configurations on the operation and system stability of ULHP. The experiments results showed that both these two ULHP prototypes can work under small angles, meeting the demand of working under multiple orientations. Specially, the parallelogram evaporator configurations showed more superior performance with little gravity assistance by better suppressing the flow instability. This kind of ULHP could not only start up under $15^{\circ}$ inclination, but also its average evaporator temperature difference between angles was limited in 4\%, the largest difference was less than 10\%. Nevertheless, the ULHP with trapezoid configuration couldn't work until the placed angles increased to $30^{\circ}$, while its average evaporator temperature difference between angles and the largest difference for the trapezoid one achieved $7.8 \%$ and $20 \%$ respectively. The parallelogram configuration made contribution on ensuring the one-way forward circulation of the working fluid inside ULHP, the response of start-up process therefore was faster. The "liquid pool" structure formed in parallelogram configuration also played an important role in decreasing the pressure and temperature fluctuation and easing the flow instability, which not only enhanced the heat transfer capability of ULHP, but also effectively reduced the damage to the battery system. BTMS could work more stably with ULHP whose channel configuration inside the evaporator was in parallelogram.

ultra-thin, heat transfer characteristic, multiple orientations, differences, operation stability

doi: 10.1360/N972016-00036 